\title{
Effect of oestrogen on fetal survival in the rabbit
}

\author{
S. Badawy and R. Abdul-Karim \\ Department of Obstetrics and Gynecology, Reproductive Biology Unit, Upstate Medical Center, \\ Syracuse, New York, 13210, U.S.A.
}

\begin{abstract}
Summary. Pregnant rabbits (Day 18) were treated i.m. for 3 days with $10 \mu$ g oestradiol$17 \beta / \mathrm{kg}$. The number of dead fetuses was significantly greater than in the control animals but corpus luteum weight and peripheral progesterone concentrations were not affected. Fetal death was therefore not due to luteolysis.
\end{abstract}

\section{Introduction}

High doses of oestrogens given to the pregnant rabbit after Day 12 of gestation produce fetal death (Reynaud, 1934), and so we investigated whether this lethal effect of oestrogen was caused by luteolysis.

\section{Materials and Methods}

New Zealand White rabbits weighing 3-4 kg each were kept under standard conditions of light and temperature. They were mated with bucks of known fertility and the day of mating was designated Day 0.

Starting on Day $18,10 \mu \mathrm{g}$ oestradiol-17/ $/ \mathrm{kg}$ were injected intramuscularly into 7 rabbits for 3 days. The oestradiol (Progynon: Schering) was made up in isotonic saline solution ( $0 \cdot 154 \mathrm{M}-\mathrm{NaCl}$ ). The 6 control rabbits received the vehicle only. On Day 20, all the rabbits were anaesthetized with sodium pentobarbitone. Blood was withdrawn from each ovarian vein, heparinized, and pooled for each rabbit according to treatment. Blood samples were also taken from the femoral vein. The blood was immediately centrifuged and the plasma was frozen at $-20^{\circ} \mathrm{C}$ until assayed for progesterone. The ovaries were removed and weighed. The fetuses and placentas were removed and counted and the number of dead fetuses noted.

Progesterone concentrations were determined by the radioimmunoassay of Thorneycroft \& Stone (1972). The antiserum was raised in rabbits to an $11 \alpha$-succinyl-hydroxyprogesterone-bovine serum albumin conjugate. The cross-reactivity, measured and calculated as described by Thorneycroft, Tillson, Abraham, Scaramuzzi \& Caldwell (1970), was $0.7 \%$ for 20a-dihydroprogesterone, $0.9 \%$ for $17 \alpha$-hydroxyprogesterone, and $0.2 \%$ for pregnenolone. The labelled progesterone was from New England Nuclear (Net-208), and the progesterone standard was from Sigma; gelatin-phosphate buffer, $\mathrm{pH} 7 \cdot 2$, and dextran-coated charcoal were used for the assay procedure. The recovery rate was $85-90 \%$. The intra- and inter-assay variations were 5 and $12 \%$ respectively. The sensitivity was $5 \mathrm{ng} / \mathrm{ml}$.

The significance of the results was assessed by Student's $t$ test and a value of $P<0.05$ was taken as significant.

\section{Results}

The results are shown in Table 1. The number of dead fetuses in the oestradiol-treated rabbits was significantly higher than in the control animals. All the dead fetuses were macerated and smaller in size than the live ones. Their placentas appeared to be normal. 
Table 1. The effect (mean \pm s.d.) of oestradiol-17 $\beta$ on various factors in pregnant rabbits

\begin{tabular}{|c|c|c|}
\hline & $\begin{array}{c}\text { Control rabbits } \\
\text { (6) }\end{array}$ & $\begin{array}{l}\text { Oestradiol-treated } \\
\text { rabbits (7) }\end{array}$ \\
\hline No. of fetuses/litter & $10 \cdot 5 \pm 3 \cdot 1$ & $8 \cdot 4 \pm 3 \cdot 2$ \\
\hline No. of dead fetuses/litter & $0.2 \pm 0.4$ & $6 \cdot 1 \pm 1 \cdot 6^{*}$ \\
\hline No. of live fetuses/litter & $10 \cdot 3 \pm 2 \cdot 9$ & $2 \cdot 3 \pm 0 \cdot 3^{*}$ \\
\hline Weight of each live fetus (g) & $3 \cdot 1 \pm 1 \cdot 0$ & $2 \cdot 7 \pm 0 \cdot 1$ \\
\hline Weight of each dead fetus (g) & $-\dagger$ & $1.9 \pm 0.4$ \\
\hline Weight of placenta/live fetus (g) & $3 \cdot 2 \pm 1 \cdot 1$ & $3.2 \pm 0.6$ \\
\hline Weight of placenta/dead fetus (g) & $-i$ & $2 \cdot 7 \pm 0.4$ \\
\hline Weight of ovaries (g/pair) & $1 \cdot 16 \pm 0 \cdot 3$ & $1.02 \pm 0.4$ \\
\hline No. of CL/ 2 ovaries & $12 \cdot 3 \pm 1 \cdot 4$ & $10 \cdot 3 \pm 3 \cdot 1$ \\
\hline \multicolumn{3}{|l|}{ Progesterone conc. ( $\mathrm{ng} / \mathrm{ml}$ ) } \\
\hline Ovarian vein & $330 \cdot 3 \pm 153 \cdot 0$ & $398 \cdot 5 \pm 220 \cdot 0$ \\
\hline Femoral vein & $8.25 \pm 3.51$ & $5 \cdot 57 \pm 1.50$ \\
\hline
\end{tabular}

* Significantly different from control values $P<0.001$.

† One fetus only.

\section{Discussion}

The present study confirms that a high dose of oestradiol-17 $\beta$ has an adverse effect on fetal survival in rabbits. The progesterone concentrations and the similarity of luteal and ovarian weight in the treated and untreated rabbits show that there was no decline in the function of the corpus luteum.

The present results therefore support the suggestion of Makler \& Morris (1971) that the detrimental effects of oestrogen on rabbit embryos is not due to luteolysis. This conclusion is not unexpected because it is known that oestrogens are luteotrophic in the rabbit (Keyes \& Nalbandov, 1967; Armstrong, Jackanicz \& Keyes, 1969; Hilliard, Saldarini, Spies \& Sawyer, 1971). They are essential for the maintenance of secretion of progesterone by the corpus luteum, and progesterone is necessary to support gestation in this species. Small doses of oestradiol can maintain pregnancy in rabbits after hypophysectomy (Robson, 1937, 1939; Greep, 1941), treatment with antiserum to LH (Spies \& Quadri, 1967), or the destruction of the follicles by X-ray irradiation (Keyes \& Nalbandov, 1967). The ability of oestrogens to stimulate progesterone formation in luteal tissue in vitro has also been demonstrated (Fuller \& Hansel, 1971). There are various possible mechanisms whereby oestrogen could exert its effect, e.g. by affecting prostaglandin and oxytocin secretion and hence myometrial activity (Blatchley et al., 1971; Bedford, Challis, Harrison \& Heap, 1972), by decreasing blood flow in the maternal placenta (Abdul-Karim \& Bruce, 1972), or by affecting metabolic processes (Jacob, Lal \& Sharma, 1975).

We thank Dr K. Sundaram, The Population Council, Rockefeller University, New York, for the progesterone antiserum and Miss Mary Haviland for her technical assistance.

\section{References}

Abdul-Karim, R.W. \& Bruce, N.W. (1972) The regulatory effect of oestrogens on fetal growth. II. Uterine and placental blood flow in rabbits. $J$. Reprod. Fert. 30, 477-480.

Armstrong, D.T., Jackanicz, T.M. \& Keyes, P.L. (1969) Regulation of steroidogenesis in the rabbit ovary. In The Gonads, pp. 1-25 Ed. K.W. McKerns. Appleton-Century-Crofts, New York.

Bedford, C.M., Challis, J.R.G., Harrison, F.A. \& HEAP, R.B. (1972) The role of oestrogens and progesterone in the onset of parturition in various species. J. Reprod. Fert., Suppl. 16, 1-23. 
Blatchley, F.R., Donovan, B.J., Poyser, N.L., Horton, E.W., Thompson, C.J. \& Loow, M. (1971) Identification of prostaglandin $F_{2} \alpha$ in the uteroovarian blood of guinea pigs after treatment with oestrogen. Nature, Lond. 230, 243-244.

Fuller, G.B. \& Hansel, W. (1971) Estrogen-stimulated progesterone synthesis by rabbit corpora lutea in vitro (35616). Proc. Soc. exp. Biol. Med. 137, 539-542

GREEP, R.O. (1941) Effects of hysterectomy and of estrogen treatment on volume changes in the corpora lutea of pregnant rabbits. Anat. Rec. 80, 465-477.

Hilliard, J., Saldarini, R.J., Spies, H.G. \& Sawyer, C.H. (1971) Luteotrophic and luteolytic actions of LH in hypophysectomized, pseudopregnant rabbits. Endocrinology 89, 513-521.

JaCOB, D., LaL, G. \& Sharma, M.M. (1975) Effect of stilbestrol on the uterine phosphatases of the rabbit. Contraception 11, 643-649.

Keyes, P.L. \& Nalbandov, A.V. (1967) Maintenance and function of corpora lutea in rabbits depend on estrogen. Endocrinology 80, 938-946.

MAKLer, A. \& Morris, J.M.C. (1971) Effect of postcoital estrogen on uterine carbonic anhydrase. Fert. Steril. 22, 204-208.
ReYNAUd, R. (1934) Thesis, Algiers. In Patterns of Mammalian Reproduction, p. 200. Ed. S. A. Asdell. Comstock Publishing Associates, Cornell University Press, Ithaca, New York, 1946.

Robson, J.M. (1937) Maintenance by oestrin of the luteal function in hypophysectomized rabbits. $J$. Physiol., Lond. 90, 435-439.

RoBson, J.M. (1939) Maintenance of pregnancy in the hypophysectomized rabbit by the administration of oestrin. J. Physiol., Lond. 95, 83-91.

SPIES, H.G. \& QUADRI, S.K. (1967) Regression of corpora lutea and interruption of pregnancy in rabbits following treatment with rabbit serum to ovine LH. Endocrinology 80, 1127-1132.

ThORNEYCROFT, I.H. \& Stone, S.C. (1972) Radioimmunoassay of serum progesterone in women receiving oral contraceptive steroids. Contraception 5, 129-146.

Thorneycroft, I.H., Tillson, S.A., Abraham, G.E., Scaramuzzi, R.J. \& Caldwell, B.V. (1970) Preparation and purification of anti-bodies to steroids. In Immunologic Methods in Steroid Determination, pp. 63-86. Eds F. G. Peron \& B. V. Caldwell. Appleton-Century-Crofts, New York.

Received 30 August 1977 